\title{
MORE THAN JUST GOOD GRADES: CANDIDATES' PERCEPTIONS ABOUT THE SKILLS AND ATTRIBUTES EMPLOYERS SEEK IN NEW GRADUATES
}

\author{
Manuel Salas Velasco \\ Department of Applied Economics, University of Granada, \\ Campus Cartuja, 18071 Granada, Spain \\ E-mail:msalas@ugr.es
}

Received 10 February 2011; accepted 19 June 2011

\begin{abstract}
There is a common belief among university students that they have to study hard attempting to earn high grades because employers are targeting graduates with outstanding academic records. However, this idea does not seem to capture what is actually happening in organizations, as firms value more aspects related with personality and other personal qualities of young graduates. We present a case study of the hiring process of recent university graduates to test these hypotheses. The methodology used follows a twostage approach. Principal component analysis allows us to identify first key categories of skills and attributes that influence the selection process. Then, using econometric analysis, a matrix classifies them according to employer size and type, degree, position and industry. The results show that soft skills (personality and other qualities) are the most required attributes in the selection process. Good academic records only matter in the public sector.
\end{abstract}

Keywords: principal component analysis, econometrics, recruitment and selection, graduate labor market, university grades, soft skills, human resources, signaling.

Reference to this paper should be made as follows: Salas Velasco, M. 2012. More than just good grades: candidates' perceptions about the skills and attributes employers seek in new graduates, Journal of Business Economics and Management 13(3): 499-517.

JEL Classification: M21, M50, C21, C93.

\section{Introduction}

Firm specific advantages, which can be defined as those specific resources and capabilities that have been developed and accumulated internally in the firm and largely take the form of the possession of distinctive skills and intangible assets, is one of the most important explanatory variables of business performance (Strandskov 2006). Consistent with this perspective, human resources and their management play a critical role in the creation and sustaining of competitive advantage for the organization (Kazlauskaite, Bučiūnienè 2008), and the process of recruiting and selecting the right staff seems to be the most important (and challenging) function of any human resources department. Employers are interested in attracting and hiring the very best candidates reducing the risk of picking up the 'wrong' person. In fact, person-organization (P-O) fit, which can 
be defined as the degree of congruence or match between a person and the organization, is a topic that has attracted the attention of both scholars and managers during the last decades (Kristof 1996); person-organization mismatches lead to low productivity, shirking, absenteeism and quits. Positive and significant effects on labor productivity are found for organizations that utilize more sophisticated human resource planning, recruitment and selection strategies (Koch, McGrath 1996).

In this line, this article focuses on the recruitment of new university graduates. Due to skill-biased technical progress, a highly educated staff can be seen, clearly, as a source of competitiveness (Kravis, Lipsey 1992). Graduates are thought that are not only smart and able to learn quickly, but are adaptable, responsible, and able to work with others too (Carless 2007). The graduate recruitment process concerns how they are attracted to the organization - through ads, personal networks, and so forth - and the offer process too, which includes deciding to whom to extend an offer which often requires extensive interviewing. The key aspect in this process is that recent graduates normally do not have job experience and they only bring to the organization a 'visible' asset such as their grades and an 'invisible' one such as their personality. Although many employers may look for a combination of both, the crucial point comes down to specifying the contexts under which the first one or the second one prevails; they are likely to differ according to the kind of job/position and/or labor market segment (e.g., private/public sector).

There is a common belief among university students that they have to study hard attempting to earn high grades because employers are targeting graduates with outstanding academic records. The main research question in this article is to explore employers' emphasis on grades during the hiring process for new graduates. Answering this question is important with clear education policy and social welfare implications. Student time and effort are arguably the most important inputs to education, for given levels of ability. If employers really value good grades - and full information contained in transcripts - then students will try to study hard during their degrees ${ }^{1}$. This student behavior would improve clearly the (internal) efficiency of universities as students would complete their studies on time and they would not drop out. And, assuming that universities (or teachers) meet high standards and honest grading, students would finish their university studies with higher levels of competences (external efficiency improvement) ${ }^{2}$. Otherwise, if employers value more personal qualities, then utility-maximizing students can choose whether to meet the standards; they could behave differently during their studies in the sense that they would be interested in getting a 'sheepskin' only and/or would assign more value to leisure. Despite its importance, the hiring process in the graduate labor market is poorly understood and hardly studied. It is simply difficult to

\footnotetext{
${ }^{1}$ If there were perfect information, then employers could distinguish individual productivity and pay corresponding wages; students could each pick different levels of effort and earn corresponding wages (Costrell 1994).

${ }^{2}$ On the contrary, easy grading practices may have negative effects on the educational system itself since they negatively influence students' incentives to provide effort in knowledge acquisition (Figlio, Lucas 2004) and reduce pressure on College administrators to improve teaching quality (Bishop, Woessman 2004).
} 
assemble the relevant data. In practice, we can think mainly of two approaches to know what employers really want. We can either design a recruiter survey to ask directly employers (or interviewers) what specific job skills and other personal characteristics they seek in applicants or we can design an employee survey to ask job candidates about the selection criteria taken into account by employers when filling vacant positions. However, large representative employers surveys focused on new university graduates are not available internationally. And, so far, only two graduate surveys are available in Europe (CHEERS and Reflex) although they contain information only on the level of competence required by the posts but they do not ask recent graduates how personal attributes and academic ability contributed to getting their first job, in other words, how employers valued them during the hiring process.

This second approach - employees' perceptions - is used in this article in the attempt to gain a thorough understanding of the factors that influence the selection decision process of new graduates in business-related degrees. Next section reviews the literature on the job search which incorporates both hard and soft skills in the selection decision process. There is no attempt to produce a comprehensive systematic literature review, rather the intention is for the article to act as a catalyst for trying to understand graduate recruitment and selection as a process. In the third section we describe the data collection process, target sample and response rate; discuss the representativeness of the final sample; and present the preliminaries of our study. Fourth section explains the methodology used for analyzing the data which follows a two-stage approach (PCA + $\mathrm{MR}$ ): principal component analysis followed by a multiple regression on the obtained components. The penultimate section discusses the results that allow us to define the 'ideal economist' for the organizations by posts, industries, university degrees, employer size and type of employer, mainly. Last section contains concluding remarks and possible extensions of the current research.

\section{Literature review}

Matching the right person to the right job is no trivial task. Theoretical models of labor market assume very often that firms know the productivity of all applicants and pay wages proportionate to those productivities. In the presence of heterogeneity among the labor force and imperfect information by employers, this assumption is overly strong (Guasch, Weiss 1981). Despite best efforts, worker quality is not known with certainty at the time of hire (Lazear 1995). In practice, both employers and job-seekers possess at best imperfect information. It is not surprising that both parties invest considerable time and monetary resources into the process of job search. In some cases, this takes the form of specific institutional arrangements, like professional degrees, titles or competitive exams needed for access to particular occupations. In the absence of such arrangements, the initial match between available and required human capital is likely to be heavily dependent on signals emitted by one party and picked up by the other (Spence 1973). Signaling is one way of resolving adverse selection problems. When skills of prospective employees are readily identified - which is partly associated with hard skills - search for a worker is more economical. Employers can use educational 
credentials to decide which workers to place in jobs demanding more cognitive skills. They may do this because it is expensive to measure cognitive skills directly, so they use schooling as a proxy (Gottfredson 1985). In this signaling framework, Weiss (1983) considers a model of education in which students are tested. He assumes that passing grades are productive in themselves: if two students of the same type receive different grades, they have different market values.

What makes a credential useful for hiring university graduates? A credential can be informative in two ways. First, it may mean that the holder of the credential has knowledge or skills that apply directly to a job. This might be the case of graduates with an MBA. For example, in the banking sector, hard skills such as knowledge of own field (financial mathematics, accounting or auditing) and technical skills (computer skills) are thought to be crucial, and graduates are supposed to have gained them during their master's degrees. Second, it may mean that the holder of the credential has innate abilities (e.g., intelligence) that tend to make one more productive on the job. In this respect, students can signal their ability by obtaining a difficult major and achieving a high grade point average (GPA) in order to get a place in MBAs of universities with a high reputation. The informational value of the credential comes from the fact that the employer assumes it is positively correlated with having greater ability. And we should expect to see employment practices consistent with signaling, that is, workers receive wages equal to their expected productivities at their jobs given the information observable to firms including university and grades. For example, in the Silicon Valley area (in California) graduates from the Stanford School of Business have more chances to get a good job and they are paid higher starting salaries than their peers who graduated from other nearby institutions such as San José State University. But average starting salaries can be a misleading indicator of 'graduate value' as they can fluctuate over time and be subject to wider economic pressures either in certain business sectors (as currently with investment banking) or more generally across the economy. In any case, the claim that prestigious institutions provide higher financial returns to their graduates has not been clearly illustrated to date (Chevalier, Conlon 2003).

Believing in signals can save money to the employer because from a group of CVs received, a job interview with four or five candidates could be enough to find the best one. Consistent with previous graduate selection research (e.g., Hodgkinson, Payne 1998; Keenan 1995; Stewart, Knowles 2000), the interview is an integral part of the selection process. Through interviews, the employer is able to verify the accuracy of the signals. Learning from previous recruitment and selection processes is a key factor that determines the trustworthiness of signals. But if firms do not rely on grades, because of the grade inflation observed over time (Rojstaczer, Healy 2010) ${ }^{3}$, and/or they value more unobservable soft skills in candidates, then signals do not form a solution to the problem of incomplete information on the job market. In the former case, it is argued that grade inflation reduce in fact the value of grades as signals of productivity and

\footnotetext{
3 "Grade inflation" is a term coined to describe the tendency to inflate grades, that is to reduce the academic standards which lead to given levels of academic performance.
} 
therefore the capacity of employers to select from a group of graduates (Chan et al. $2007)^{4}$. In the latter case, beyond credentials, firms must invest important resources time and money - to find the best candidate for the position to be filled. This can include formal testing, psychological profiling and multi-round interviews (Dodd 1970a, b, c, d).

Is the graduate labor market nowadays valuing signals such as good universities and grades? Although over the last forty years research on employee recruitment has increased dramatically (Breaugh 2008), a review of the literature indicates that little research has been done exploring these issues when hiring new graduates. For example, Hesketh (2000) uses data on 372 British employers who recruited graduates during December 1997. The results show that employers target particular universities when recruiting new graduate hires. Two-fifths of the sample revealed that they focused their attentions on particular institutions when recruiting for specific posts - it appears that employers still prefer those institutions which command high A-level points scores from entrants such as Oxford and Cambridge. In fact, some organizations, such as management consultants and banking firms, are taking into account the rigorous interview process that potential employees have undergone for university entrance selection, such as at Oxbridge, and using this as a signifier of future potential; employers may judge that higher education has undertaken a first stage of their selection process for them (Keep, James 2010).

Recently, using the Reflex graduate survey, Salas Velasco (2011) studies the transition from university to work. The estimation results of the Han and Hausman ordered logit model for duration data for 17,327 individuals reveal that European graduates with better average grades when they finished their university degrees - compared to other students (classmates) that graduated from the same study program - increase the probability of finding the first job sooner, ceteris paribus. The author suggests two readings for his finding. On the one hand, good grades (or marks) can be seen as a positive signal of productivity or effort by employers, if they associate educational success with success in the workplace; so graduates with better grades are expected to receive more job offers. On the other hand, students with outstanding academic records are, in general, more ambitious, anxious, and involved individuals, and they are able to search more efficiently job opportunities - greater ability to obtain relevant information on vacancies and/or better aptitudes to perform in an interview. But Reflex survey does not allow to know to what extent good grades were valued by employers during the hiring process. Likewise, another practical way to recruit 'right' graduates, as we have said before, is to use other signals such as the institutional quality. This information was indeed included in the data set from the CHEERS graduate survey (the predecessor of Reflex), but Salas Velasco (2007) estimates duration models (log-normal regression - accelerated failure-time form) using 13,510 European graduates and proves that, ceteris paribus, the reputation of the university does not explain the time-to-first-job. However, the survey does not contain questions related to the value employers placed on the quality of the institutions during the hiring process.

\footnotetext{
${ }^{4}$ Another interesting theoretical perspective on the issue of the informative content of grades appears recently in Popov and Bernhardt (2011).
} 
The question still remaining is what cognitive and non-cognitive skills employers really want. In the early nineties, Carnevale et al. (1990) highlighted the economic importance of sixteen skills that employers considered were workplace basics. Technical competences, skills that enable people to communicate effectively on the job, adaptability skills that enable workers to be flexible in the workplace, the group effectiveness skills that enable people to work together productively, and the influencing skills that enable people to bring a task to completion were the essential skills employers wanted (Carnevale et al. 1990). With regard to university graduates, personal characteristics seem to be the most valued attributes in recent graduates from the employers' point of view. Interesting, the set of specific skills has not changed greatly for the last three decades: communication, problem-solving, analysis and interpersonal skills feature alongside knowledge and intelligence in organizational graduate specifications; and, increasingly, 'graduate attributes' are more important in the recruitment process than the graduates' degree subject (Harvey 2000).

In the 90 s, campus recruiting was considered by many organizations as the most effective way of attracting graduates, mainly in the USA (Turner et al. 1997). This latter article showed from a survey of 111 campus recruiters their perceptions and practices of campus activities; verbal communication skills and work experience - and to a lesser extent academic performance - were the most important personal characteristics for selecting applicants (Turner et al. 1997). For the UK, results of research into the graduate recruitment and selection practices of 30 British small to medium-sized enterprises (SMEs) and the skills being sought by employers suggest that, unlike large employers which are more likely to provide graduate development programs, SMEs value transferable skills and that small employers expect an immediate contribution from graduate recruits (Stewart, Knowles 2000). In this line, Hesketh (2000), on the basis of the data cited before, finds that employers are keenly interested in graduates with good communication skills and the ability to learn new material - they are less concerned with the numerical and information technology (IT) skills of graduates. But, on average, employers found it difficult to recruit graduates with suitable skills in just three of nine skill areas: teamwork, self-management and technical skills (Hesketh 2000). More recently, Branine (2008), using data from around 300 UK-based employers, asserts that the process of graduate recruitment and selection in the UK has become more personrelated than job-oriented because many employers are more interested in the attitudes, personality and transferable skills of applicants than the type or level of qualification acquired. In addition, although some of the usual methods such as interviewing remain popular, there is a greater variety of ways by which graduates are attracted to and selected for their first jobs (Branine 2008).

From the graduates' perspective, using the Reflex graduate survey, Salas Velasco (2011) shows recently the ratings given by European university graduates to nineteen competences on a seven-point scale (from $1=$ lowest to $7=$ highest). The competences rated as highly required in their current job (five years after graduation) relate to: (1) mobilizing their own capacities (e.g., using time efficiently, performing well under pressure); (2) mobilizing others (e.g., working productively with others, coordinating activities, making meaning clear to others); and (3) having good specialist knowledge (e.g., mastery 
of own field, ability to rapidly acquire new knowledge, ability to use computers and the internet). As we can see, graduates consider that both cognitive and non-cognitive skills are important for their jobs. Although the author provides empirical support on the role played by universities for learning - clearly, much of the provision of learning at the European universities is through lectures (academic knowledge) given by professors, still we know little about the role of the educational institutions in the development of non-cognitive skills.

\section{Research design}

\subsection{Target sample and response rate}

An empirical study was conducted in 2006. The objective of the research was to clarify some of the issues raised above. The research was based primarily on a graduate postal survey from a pilot questionnaire adequately validated. The context of the study was a single survey of economists. Sampling and selection errors were controlled by using the entire population for the research. Specifically, a 29-item questionnaire was administered via postal mail to all former students $(N=982$ individuals $)$ who finished a degree at the University of Seville Management School in the academic year 2001/2002 in one of the four possible degrees offered by the School: Business Studies, Economics Sciences, Management Sciences, and Marketing Studies.

We obtained a response rate somewhat superior to 20 percent - in total the survey was completed by 200 respondents, an acceptable rate considering the extension of the questionnaire - and a very common response rate too in social sciences and marketing research. However, in order to assess how accurately the sample represents the target population, Table 1 compares key sample characteristics with a set of known population characteristics obtained from the University of Seville Enrolment Office. As shown in Table 1, in general, the similarity of both data sets with respect to sex, age and degrees allows an adequate representativeness of the sample ${ }^{5}$.

Table 1. Representativeness of the sample

\begin{tabular}{lcc}
\hline & Sample & Population \\
\hline Business Studies & $54.2 \%$ & $62.0 \%$ \\
\hline Economics Sciences & $20.0 \%$ & $12.0 \%$ \\
\hline Management Sciences & $15.0 \%$ & $17.0 \%$ \\
\hline Marketing Studies & $10.8 \%$ & $9.0 \%$ \\
\hline Gender (=1 males) & $40.3 \%$ & $40.1 \%$ \\
\hline Age (in years) & 28.9 & 29.2 \\
\hline
\end{tabular}

Source: own calculations from the graduate survey and the University of Seville Enrolment Office

\footnotetext{
${ }^{5}$ Although a growing number of researchers regard the Web as a speedy, cheap and effective alternative to traditional data collection methods, we did not have information on their personal e-mail addresses.
} 


\subsection{What perceptions have been studied?}

Among other purposes, several questions in the survey sought information about usage of human resource management (HRM) practices in hiring recent (new) economists. The personnel selection process requires employers to decide among candidates characterized by multiple attributes. Candidates' perceptions about the skills and other attributes sought by employers provide a valuable source of information ${ }^{6}$. We are aware of the subjectivity of this procedure to determine the hiring criteria, nonetheless it is difficult in practice to find what employers are in fact recruiting graduates; and the difficulty is even higher in Spain because on-campus recruitment is very rare. In any case, we have found other researchers who use a similar methodology (e.g., Peppas 2006). In this research, the author emailed a questionnaire to 248 individuals who had been involved in hiring. It consisted of two sections. The first section gathered demographic information. The second section consisted of a list with 26 job selection criteria; respondents indicated, from 1 (not important) to 5 (very important), what they felt was the importance of each attribute in hiring new employees. In our research we followed a similar evaluation system. We asked graduates to rate on a 5-point Likert scale the degree of importance they ascribed to thirteen job attributes related to the access to their first employment after graduation - excluding casual jobs. Job attributes were related to:

- University grades.

- Knowledge of own field or discipline, and languages.

- Experience studying abroad and postgraduate education.

- Work experience (including internships).

- Computer skills.

- Soft skills. ${ }^{7}$

Figure 1 depicts the self-reported ratings, from 1 (not important) to 5 (very important), given by respondents (self-employed are not included in the analysis). Although, in practice, firms are thought to value both academic ability and social skills, which are complements in production, our results suggest that employers seek soft skills rather than specific technical and cognitive skills in new economists. Clearly, aspects related to personality and other personal qualities were more important than, for example, experience/internships during higher education (HE) or their university grades, to get their first job $^{8}$. Similarly, Peppas (2006) found that motivation, enthusiasm and self-confidence appeared as the highest-ranked criteria.

However, from our survey we are not able to know the true reasons why employers, on average, did not value good grades in the hiring process. A future research, using em-

\footnotetext{
${ }^{6}$ In this article, we use the words candidate, graduate, respondent and employee as interchangeable terms.

${ }^{7}$ Soft skills is a sociological term relating to a person's EQ (Emotional Intelligence Quotient), the cluster of personality traits, social graces, communication, language, personal habits, friendliness and optimism that characterize relationships with other people.

${ }^{8}$ Although internships and previous work experience would enable graduates to pick up relevant skills which may be pertinent to their first job, they were not necessary according with the economists in our sample.
} 


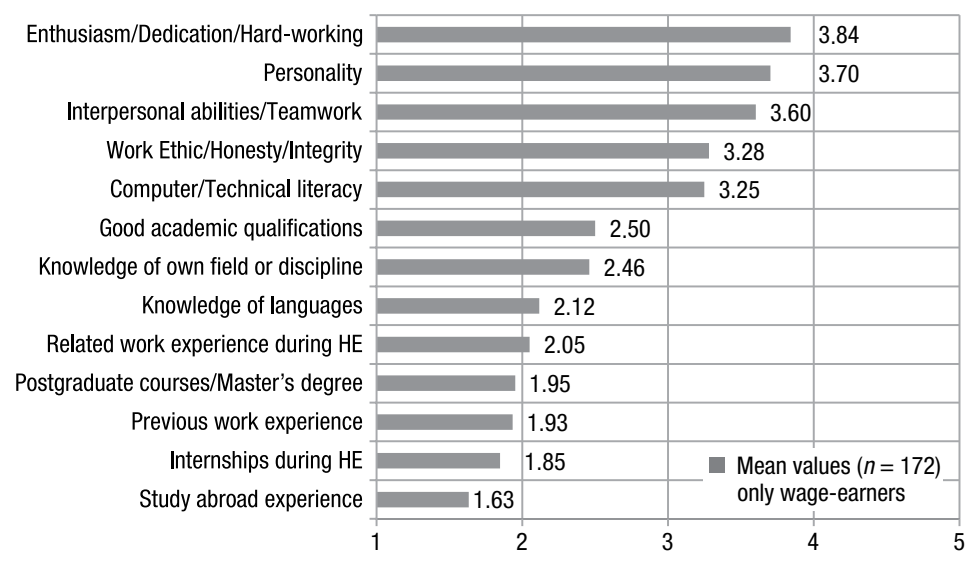

Fig. 1. What do employers really want? Skills, values and attributes sought from new economists. Candidates' perceptions

ployers (or interviewers) surveys, could give us the answer. In any case, our results are in line with other studies which use employers surveys. For example, Ray and Stallard (1994) identified and analyzed the perceptions of human resource managers regarding criteria for the screening and selection of college and university business graduates for employment. This research involved a national survey of practicing HRM professionals. A questionnaire was developed to solicit perceptions about the importance of specific criteria. Communication skills were the most highly rated criteria by the participants (202 usable returns); other skills representing factors that HRMs perceived as important were human relations skills, problem-solving skills, and knowledge of software applications. However, it is not still clear in the literature how employers (o interviewers) perceive and/or capture motivation, enthusiasm and other intangible qualities in a 30-minute job interview. Often measurement is based on employers' perceptions of their interaction with candidates at interview, but this is an area that, in general, is under explored in surveys.

\section{Methodology}

As we have shown in the previous section (Fig. 1), we know, from the candidates' perceptions, how different job attributes, including good grades, did matter when getting their first employment as economists. But, clearly, this descriptive information gives us only limited insight and a deeper analysis is needed. Our aim now is to explore how those job attributes vary according to explanatory factors such as employer size (and type), university degree, position and industry, mainly. This is possible with the econometric analysis (multiple linear regression) where the dependent variable would be the ratings given by the respondents. However, it would be impracticable or tedious to run thirteen equations. Therefore, we propose a two-stage approach for the analysis. In a first stage, our strategy is to reduce the information given in Figure 1 into big groups of selection criteria by principal component analysis (PCA) and then, in a second stage, to run a regression analysis for each one. 


\subsection{Principal component analysis as a practical tool to classify selection criteria}

PCA is a variable-reduction procedure. It is useful when we have data on a number of variables but believe that there is some redundancy in those variables. PCA involves a mathematical procedure that transforms a number of possibly correlated variables into a smaller number of uncorrelated variables called principal components. The application of a PCA prior to multiple linear regression requires greater time and effort as more statistical analyses must be performed and the identity of new variables (factors) obtained from the original set of explanatory variables must be interpreted.

Principal component analysis can extract meaningful information from the selection criteria shown in Figure 1. PCA creates factor scores that will account for most of the variance in the observed variables 9 . Table 2 presents the factor load matrix resulting from PCA where four factors capture $72 \%$ of the overall variance ${ }^{10}$. The responses for items of importance to successful interviewing were clustered thus into the following four categories:

1. Soft skills (personality and other qualities).

2. Practical experience.

3. Master/languages/study abroad.

4. Hard skills (academic ability/knowledge/computer skills).

\subsection{What are the determinants of perceptions?}

Econometric analysis allows us to identify the factors behind the demand for hard and soft skills - and other attributes - in the graduate labor market. If we had used the original answers as a dependent variable, that is, the self-reported rates on a 5-point scale, then qualitative response models (e.g., an ordered logit model) are more satisfactory for the analyses. However, we have transformed the thirteen original attributes into four factors and now the values for them are measured on a continuous level. So, the ordinary least squares (OLS) fit to factors from principal component analysis is more appropriate. The regression equation in such a case becomes (one for each of the four factors in Table 2):

$$
y=\beta_{0}+\beta_{1} x_{1}+\beta_{2} x_{2}+\ldots+\beta_{n} x_{n}+\text { error, }
$$

where $y$ measures the value of the factor for each individual.

The regression analysis includes as explanatory variables $\left(x_{1}, x_{2}, \ldots, x_{n}\right)$ the position/ post hold by the graduate, employer size and type, industries, university degrees and other control variables such as type of contract, age and gender. The error term captures other influences which are not observed. Table 3 presents the values of the estimated parameters beta (coefficients). The most required skills and attributes from candidates in the recent economists' selection process are summarized in Table 4.

\footnotetext{
${ }^{9}$ See Krzanowski (1988), Jackson (1991) and Jolliffe (2002), among others, for further details.

${ }^{10}$ In Table 2, selection criteria are listed in the same order they appeared in the questionnaire.
} 
Table 2. Component score coefficient matrix

\begin{tabular}{|c|c|c|c|c|}
\hline & FACTOR 1 & FACTOR 2 & FACTOR 3 & FACTOR 4 \\
\hline Good academic qualifications & -0.09 & -0.08 & 0.13 & 0.44 \\
\hline Postgraduate courses/Master's degree & -0.09 & -0.10 & 0.34 & 0.16 \\
\hline Study abroad experience & -0.03 & -0.03 & 0.46 & -0.16 \\
\hline Internships during HE & -0.07 & 0.50 & -0.07 & -0.15 \\
\hline Related work experience during HE & -0.03 & 0.45 & -0.09 & -0.04 \\
\hline Previous work experience & -0.05 & 0.36 & 0.01 & -0.01 \\
\hline Knowledge of own field or discipline & -0.02 & -0.04 & -0.16 & 0.60 \\
\hline Knowledge of languages & 0.00 & -0.03 & 0.43 & -0.11 \\
\hline Computer/Technical literacy & 0.15 & -0.14 & -0.05 & 0.36 \\
\hline Personality & 0.28 & -0.03 & -0.03 & -0.05 \\
\hline Interpersonal abilities/Teamwork & 0.29 & -0.10 & -0.06 & 0.07 \\
\hline Enthusiasm/Dedication/Hard-working & 0.29 & -0.02 & -0.03 & -0.09 \\
\hline \multirow[t]{2}{*}{ Work Ethic/Honesty/Integrity } & 0.25 & 0.02 & -0.04 & -0.06 \\
\hline & 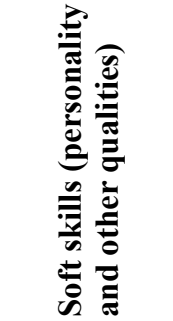 & 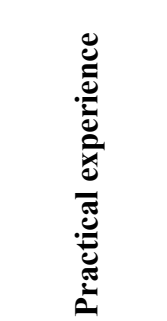 & 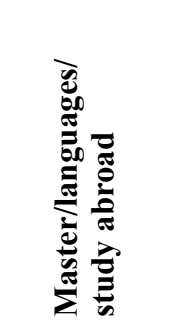 & 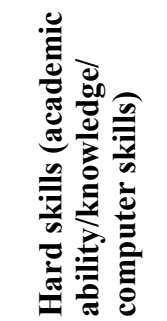 \\
\hline
\end{tabular}

Extraction Method: Principal Component Analysis

Rotation Method: Varimax with Kaiser Normalization

Source: author's calculations

\section{Discussion of the empirical findings}

The recruitment and selection process usually begins with a definition of the 'ideal candidate'. This term refers to the profile of an applicant who would best 'fit' the job. The profile may be more or less precisely defined in terms of key skills. While the emphasis of the present study still lies on understanding what attributes employers want from graduates in business, economics, management, and marketing, an additional aspect is explored: the existence and nature of sub-groups of recruiters who prioritize different aspects of the candidate's qualifications. Based on the econometric analysis, selection criteria are intimately related to soft skills, although hard skills and other characteristics are screening devices too to avoid unprofitable candidates. 


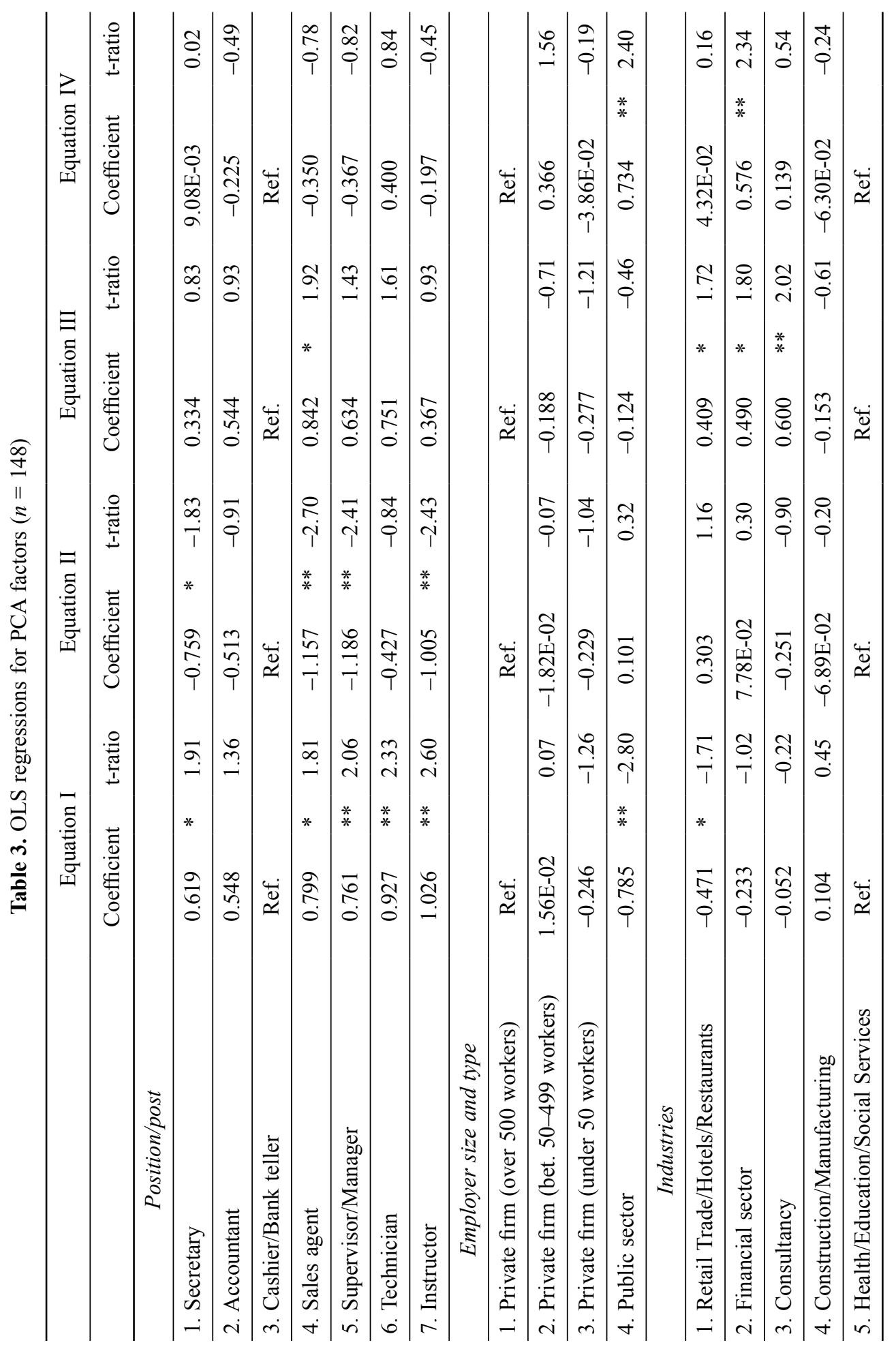




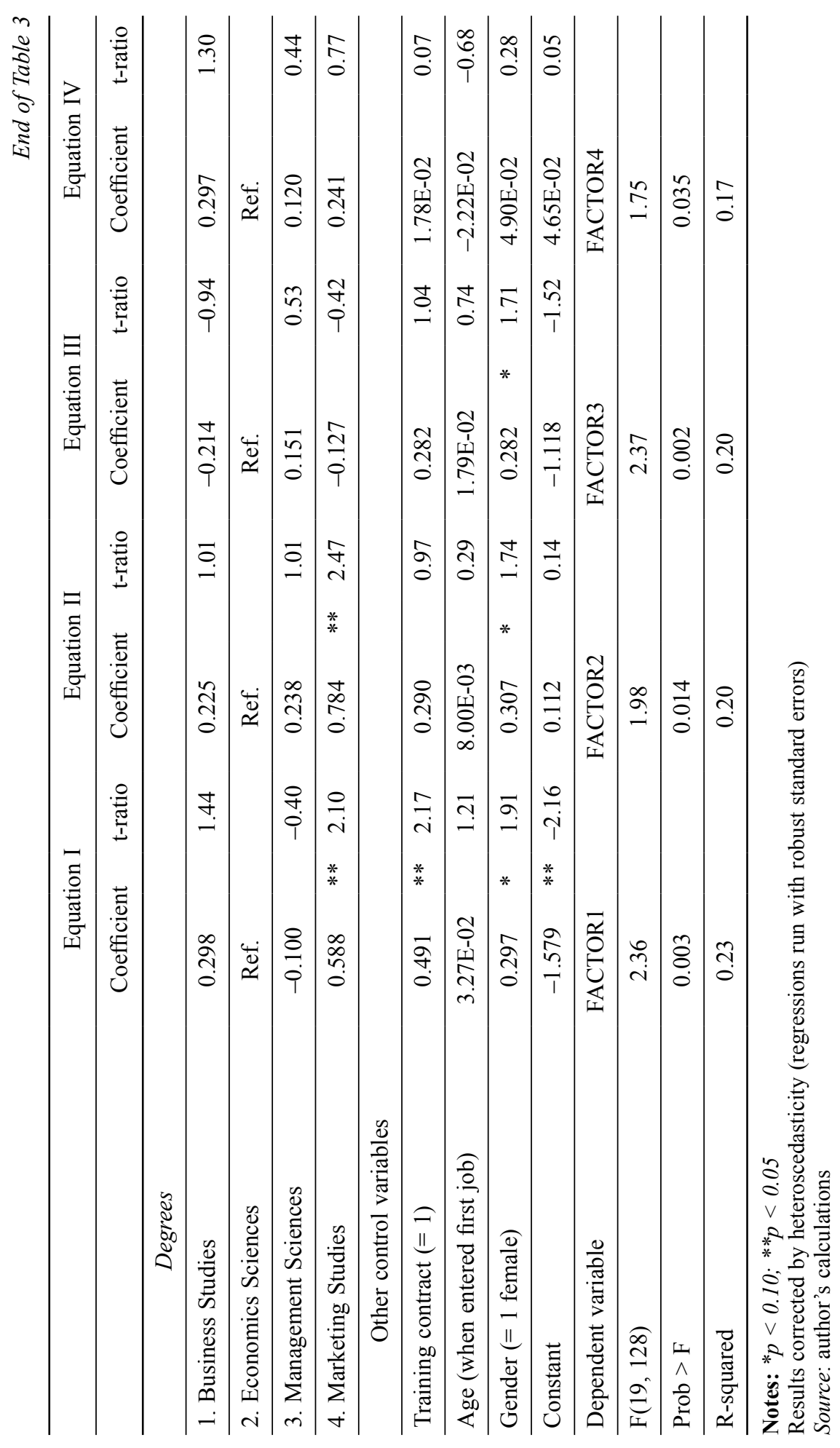


Table 4. Matrix of the most required skills and attributes from candidates in the new economists' selection process

\begin{tabular}{|c|c|c|c|c|}
\hline & 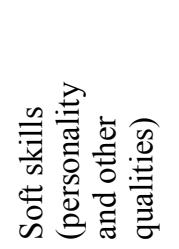 & 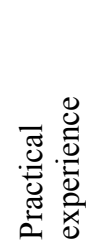 & 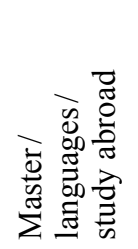 & 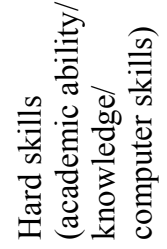 \\
\hline \multicolumn{5}{|l|}{ Position/post } \\
\hline 1. Secretary & • & $\circ$ & & \\
\hline \multicolumn{5}{|l|}{ 2. Accountant } \\
\hline 3. Cashier/Bank teller & \multicolumn{4}{|c|}{ Reference group } \\
\hline 4. Sales agent & $\bullet$ & $\circ$ & $\bullet$ & \\
\hline 5. Supervisor/Manager & $\bullet$ & $\circ$ & & \\
\hline 6. Technician & $\bullet$ & & & \\
\hline 7. Instructor & $\bullet$ & $\circ$ & & \\
\hline \multicolumn{5}{|l|}{ Employer size and type } \\
\hline 1. Private firm (over 500 workers) & \multicolumn{4}{|c|}{ Reference group } \\
\hline \multicolumn{5}{|l|}{ 2. Private firm (bet. 50-499 workers) } \\
\hline \multicolumn{5}{|l|}{ 3. Private firm (under 50 workers) } \\
\hline 4. Public sector & $\circ$ & & & $\bullet$ \\
\hline \multicolumn{5}{|l|}{ Industries } \\
\hline 1. Retail Trade/Hotels/Restaurants & $\circ$ & & $\bullet$ & \\
\hline 2. Financial sector & & & $\cdot$ & $\bullet$ \\
\hline 3. Consultancy & & & $\bullet \bullet$ & \\
\hline \multicolumn{5}{|l|}{ 4. Construction/Manufacturing } \\
\hline 5. Health/Education/Social Services & \multicolumn{4}{|c|}{ Reference group } \\
\hline \multicolumn{5}{|l|}{ Degrees } \\
\hline \multicolumn{5}{|l|}{ 1. Business Studies } \\
\hline 2. Economics Sciences & \multicolumn{4}{|c|}{ Reference group } \\
\hline \multicolumn{5}{|l|}{ 3. Management Sciences } \\
\hline 4. Marketing Studies & $\bullet$ & $\bullet$ & & \\
\hline \multicolumn{5}{|l|}{ Other variables } \\
\hline Training contract & $\bullet$ & & & \\
\hline \multicolumn{5}{|l|}{ Age (when entered first job) } \\
\hline Woman & - & $\bullet$ & $\bullet$ & \\
\hline
\end{tabular}

Notes: ${ }^{\circ}$ Not important; $\bullet$ Important; $\bullet$ Very important; [Blank cells: variables that have not shown statistical significance]

Self-employed excluded

Source: author's calculations 
Looking at screening in terms of soft skills (personality and other qualities), they vary mainly according to the type of position being filled. Compared to cashiers/bank tellers, which is the reference group, soft skills (values, attitudes and motivation) are highly required to supervisors and managers, technicians, and instructors; and to a lesser extent to sales agents, and secretaries ${ }^{11}$. However, there are not statistically significant differences by type of company and industries. Only in the public sector, and retail trade and hostelry industries, soft skills are not perceived as important by graduates in the recruitment and selection process. Lastly, other two variables have shown statistical significance. On the one hand, by university degrees in a business-related field, the results reveal that, ceteris paribus, soft skills should be embodied mainly in those students who got a degree in Marketing Studies. This is the result in our study, but, in general, demand for soft skills has drastically increased in importance for MBA recruiters worldwide according to the latest survey of TopMBA.com over 5,000 MBA recruiters in 36 countries. On the other hand, if an employer cannot assess a worker's productivity ex ante, firms are willing to pay to learn about a worker's true productivity. This way, during a probation period, training contracts provides employer an option in order to find the ones that $\mathrm{s} /$ he wants to retain and the ones to be fired.

With regard to hard skills - knowledge and academic ability, and computer literacy, significant differences were detected in the perceived importance of these skills in the selection processes of graduates in the public sector and financial industry (banking, insurance and other financial services). In the latter case, technical skills matter. The financial sector businesses are becoming more reliant on information technology (IT), and there is an increasing need for employees with IT skills. And firms tend to screen very carefully at recruiting as well, and usually have promotion systems that correspond well to our probation story above, at least in the first few years on the job. In the former case, public sector needs to sell its organizations as good equal opportunities employers. Therefore, as might be expected, grades matter, either directly during the selection process or indirectly in the examinations to become a civil servant. Spanish civil service exams are normally theoretical and students with good grades supposedly studied harder and they have both good study habits and better knowledge so can 'easily' get a place in the public administration.

Looking specifically at previous work experience and internships during higher education, they are most often used to inform the screening process of new graduates in Marketing Studies - and to a lesser extent, female graduates. Conversely, regardless of the position to be filled, previous practical experience is perceived by graduates as not important in the selection process. In addition, we have not found statistically significant differences by workplace size and industries.

Finally, this research shows that postgraduate courses, languages, and study abroad are marketable investments only if graduates are able to find an employment in Consultancy - and to a lesser extent in the Retail Trade/Hotels/Restaurants, and Financial industries - or they take a job as a sales agent.

${ }^{11}$ The questionnaire contained eight broad groups of entry-level positions which are normally attributed to graduates in business-related degrees. In the analysis done in this article we have considered only seven of them because the last group, 'others', was not responded by any interviewee. 


\section{Conclusion}

Organizations have always been concerned with attracting and selecting the right types of employees. This article focuses on the recruitment process of graduates and it approaches the question of 'which core attributes should recent economists offer' from the candidates' point of view. Based on a sample of young graduates in a businessrelated field from the University of Seville, Spain, the answers by graduates already on the labor market are used to deduct a list of job attributes sought by employers when recruiting for skilled vacancies. The methodology used in the data analysis follows a two-stage approach. Principal component analysis seeks to separate the signaling effect of education on first entry into the labor market from other softer qualities. In a second stage, econometrics analysis is used to develop a matrix of previously identified attributes by university degrees, type of employer, positions and industries. Among other interesting results, this research highlights the fact that we are surpassing the era where employers would hire candidates based solely on experience, grades or hard skills; and transpiring into a period where many of the soft skills - communication, teamwork, leadership and so on - are desired in recent graduates. Good academic records only matter in the public sector.

The findings of this study are expected to be useful for employers considering the introduction of new graduate recruitment programs as well as for institutions of higher education to reconsider the type of knowledge and skills they provide in order to prepare their students for the real world of work. Controversy exists within the business community concerning whether a business school education is congruent with the needs of business. The conclusions should, of course, be judged in the light of the limitations of this study and the findings must be interpreted with some caution. Future research with large representative samples of both, employers and employees surveys, would be desire. A finest methodology could include the same questionnaire to the employer and his/her employee in order to check reliability - the reliability of a study is to what extent it is bias-free. If there is a high correlation of ratings to the same questions, one can conclude reliability of the study.

In terms of topics meriting future research, the need for attention to be given to targeted recruitment in terms of skills should be emphasized. In the era of globalization, skill requirements of employers are clearly changing. Employers will have to take into account cultural differences which will shape business organization. But they will be challenged by the increase in the qualifications of the labor force as well. The massification of higher education and the huge expansion in the number of graduates entering the labor force in Europe - and other countries such as China or India - is one example. The move to mass higher education will radically alter the skilled labor population from which firms will try to recruit. So assessing how different graduates bring 'value' to the organization will become difficult. In other words, the challenge for human resource professionals will be how to separate the 'wheat' (scarce talent) from the 'straw' (abundance of university degrees). 


\section{Acknowledgments}

The author would like to thank the editor and anonymous referees for their valuable comments on an previous version of this paper.

\section{References}

Bishop, J.; Woessmann, L. 2004. Institutional effects in a simple model of educational production, Education Economics 12(1): 17-38. http://dx.doi.org/10.1080/0964529042000193934

Branine, M. 2008. Graduate recruitment and selection in the UK: a study of the recent changes in methods and expectations, Career Development International 13(6): 497-513.

http://dx.doi.org/10.1108/13620430810901660

Breaugh, J. A. 2008. Employee recruitment: current knowledge and important areas for future research, Human Resource Management Review 18(3): 103-118.

http://dx.doi.org/10.1016/j.hrmr.2008.07.003

Carless, S. A. 2007. Graduate recruitment and selection in Australia, International Journal of Selection and Assessment 15(2): 153-166. http://dx.doi.org/10.1111/j.1468-2389.2007.00377.x

Carnevale, A. P.; Gainer, L. J.; Meltzer, A. S. 1990. Workplace Basics. The Essential Skills Employers Want. San Francisco: Jossey-Bass Publishers.

Chan, W.; Hao, L.; Suen, W. 2007. A signaling theory of grade inflation, International Economic Review 48(3): 1065-1090. http://dx.doi.org/10.1111/j.1468-2354.2007.00454.x

Chevalier, A.; Conlon, G. 2003. Does it pay to attend a prestigious university? CEE DP 33 London School of Economics and Political Science.

Costrell, R. M. 1994. A simple model of educational standards, American Economic Review 84(4): 956-971.

Dodd, J. H. B. 1970a. Personnel selection - the procedure, Applied Ergonomics 1(2): 66-69. http://dx.doi.org/10.1016/S0003-6870(70)80001-1

Dodd, J. H. B. 1970b. Personnel selection - 2. Testing, Applied Ergonomics 1(3): 140-143. http://dx.doi.org/10.1016/0003-6870(70)90003-7

Dodd, J. H. B. 1970c. Personnel selection - 3. Interviewing, Applied Ergonomics 1(4): 202-206. http://dx.doi.org/10.1016/0003-6870(70)90127-4

Dodd, J. H. B. 1970d. Personnel selection - 4. Conclusion, Applied Ergonomics 1(5): 273-276. http://dx.doi.org/10.1016/0003-6870(70)90077-3

Figlio, D. N.; Lucas, M. E. 2004. Do high grading standards affect student performance?, Journal of Public Economics 88(9-10): 1815-1834. http://dx.doi.org/10.1016/S0047-2727(03)00039-2

Gottfredson, L. S. 1985. Education as a valid but fallible signal of worker quality. Reorienting an old debate about the functional basis of the occupational hierarchy, in Kerckhoff, A. C. (Ed.). Research in Sociology of Education and Socialization 5. JAI Press, Greenwich, CT, 123-169.

Guasch, J. L.; Weiss, A. 1981. Self-selection in the labor market, American Economic Review 71(3): 275-284.

Harvey, L. 2000. New realities: the relationship between higher education and employment, Tertiary Education and Management 6: 3-17. http://dx.doi.org/10.1080/13583883.2000.9967007

Hesketh, A. J. 2000. Recruiting an elite? Employers' perceptions of graduate education and training, Journal of Education and Work 13(3): 245-271. http://dx.doi.org/10.1080/713676992 
Hodgkinson, G. P.; Payne, R. L. 1998. Graduate selection in three European countries, Journal of Occupational and Organizational Psychology 71: 359-365.

http://dx.doi.org/10.1111/j.2044-8325.1998.tb00682.x

Jackson, J. E. 1991. A User's Guide to Principal Components. Hoboken, NJ: John Wiley and Sons. http://dx.doi.org/10.1002/0471725331

Jolliffe, I. T. 2002. Principal Component Analysis. 2nd edition. Springer. New York, NY.

Kazlauskaitè, R.; Bučiūnienè, I. 2008. The role of human resources and their management in the establishment of sustainable competitive advantage, Inzinerine Ekonomika - Engineering Economics 5(60): 78-84.

Keenan, T. 1995. Graduate recruitment in Britain: a survey of selection methods used by organizations, Journal of Organizational Behavior 16: 303-317.

http://dx.doi.org/10.1002/job.4030160403

Keep, E.; James, S. 2010. Recruitment and selection - the great neglected topic, SKOPE Research Paper No. 88 February.

Koch, M. J.; McGrath, R. G. 1996. Improving labor productivity: human resource management policies do matter, Strategic Management Journal 17(5): 335-354.

http://dx.doi.org/10.1002/(SICI)1097-0266(199605)17:5<335::AID-SMJ814>3.0.CO;2-R

Kravis, I. B.; Lipsey, R. E. 1992. Sources of competitiveness of the United States and of its multinational firms, Review of Economics and Statistics 74(2): 193-201.

http://dx.doi.org/10.2307/2109650

Kristof, A. L. 1996. Person-organization fit: an integrative review of its conceptualizations, measurement, and implications, Personnel Psychology 49(1): 1-49.

http://dx.doi.org/10.1111/j.1744-6570.1996.tb01790.x

Krzanowski, W. J. 1988. Principles of Multivariate Analysis: a User's Perspective. Oxford: Clarendon Press.

Lazear, E. P. 1995. Hiring risky workers, NBER Working Paper Series No. 5334. Cambridge, MA.

Peppas, S. C. 2006. Diversity in the workplace. Hispanic perceptions of the hiring decision, Employee Relations 28(2): 119-129. http://dx.doi.org/10.1108/01425450610639356

Popov, S. V.; Bernhardt, D. 2011. University Competition, Grading Standards and Grade Inflation. Available on-line at SSRN (Social Science Research Network).

Ray, C. M.; Stallard, J. J. 1994. Criteria for business graduates' employment: human resource managers' perceptions, Journal of Education for Business 69(3): 140-144.

http://dx.doi.org/10.1080/08832323.1994.10117672

Rojstaczer, S.; Healy, C. 2010. Grading in American Colleges and Universities, Teachers College Record, March 04, 2010.

Salas Velasco, M. 2007. The transition from higher education to employment in Europe: the analysis of the time to obtain the first job, Higher Education 54(3): 333-360.

http://dx.doi.org/10.1007/s10734-006-9000-1

Salas Velasco, M. 2011. Connecting higher education and the labor market: the European graduates' views, in Poulsen, M. E. (Ed.). Higher Education: Teaching, Internationalization and Student Issues. Nova Science Publishers, Hauppauge, NY, 35-80.

Spence, M. 1973. Job market signaling, Quarterly Journal of Economics 87: 355-374.

http://dx.doi.org/10.2307/1882010

Stewart, J.; Knowles, V. 2000. Graduate recruitment and selection practices in small businesses, Career Development International 5(1): 21-38. http://dx.doi.org/10.1108/13620430010309332 
Strandskov, J. 2006. Sources of competitive advantages and business performance, Journal of Business Economics and Management 7(3): 119-129.

Turner, M. R.; Tang, T. L.-P.; Moser, H. R. 1997. Campus recruiting: what the recruiters are looking for, Journal of Marketing for Higher Education 7(4): 35-48.

http://dx.doi.org/10.1300/J050v07n04_03

Weiss, A. 1983. A sorting-cum-learning model of education, Journal of Political Economy 91(3): 420-442. http://dx.doi.org/10.1086/261156

Manuel SALAS VELASCO is an Associate Professor of Economics at the University of Granada, Business and Economics School. His research interests are mainly in the areas of human resource economics, labor economics, economics of education, and applied econometrics. Among other journals, Dr Manuel Salas Velasco has contributed to Applied Economics Letters, Economics Bulletin, Higher Education, and Research in Economics. More details on his publications and CV can be found on his personal Website. 